\title{
I Love Indonesia: A Portrait of Community Streetism Punk Street Rebel Probolinggo
}

\author{
$1^{\text {st }}$ Warsono \\ Pancasila and Civic Education Department \\ Faculty of Social Sciences and Law \\ Universitas Negeri Surabaya \\ Surabaya, Indonesia \\ warsono@unesa.ac.id \\ $4^{\text {th }}$ Nining Winarsih \\ Department of Social Studies \\ Universitas Negeri Surabaya \\ Surabaya, Indonesia \\ Email: niningwinarsih10@gmail.com
}

\author{
$2^{\text {nd }}$ Sarmini \\ Pancasila and Civic Education Department \\ Faculty of Sosial Sciences and Law \\ Universitas Negeri Surabaya \\ Surabaya, Indonesia \\ sarmini@unesa.ac.id
}

\author{
$3^{\text {rd }}$ Ulin Nadiroh \\ Department of Social Studies \\ Universitas Negeri Surabaya \\ Surabaya, Indonesia \\ ulinnadiroh099@gmail.com
}

\begin{abstract}
The punk community gets negative and marginal stigma. Shabby appearance is often identified with aberrant ideology. This study aims to examine the nationalism of the Probolinggo Punk community. The data collection method of this research is qualitative with the focus of field research research with Edmund Huserl's phenomenological research design and using Lyotard's postmodernism paradigm. The determination of informants in this study is through snowball sampling. Data collection techniques are indepth interviews, observations, and documentation. Data analysis techniques through four stages, namely data collection, data reduction, data presentation and conclusion drawing. This study shows three forms of nationalism of Punk Community 1) rejecting injustice 2) love for the environment and volunteers and 3) state defense actions. The research will provide insight to the community and government to get to know the Punk community in the civic sphere and nationalism attitude.
\end{abstract}

Keywords- punk community, nationalism, identity.

\section{INTRODUCTION}

Some people consider punk groups to be a group that disturbs and disrupts public order [1]. Punk is not only a social community but it includes ideology, politics, music and lifestyle which are summarized in a subculture [2], [3] which is a differentiator from cultural culture in general [4], [5]. The term punk began to be known to the public in 1970 [6]. Punk is a social community in which there is a culture that develops and produces subcultures that become an identity lifestyle, or choices for adherents [7]-[10].

The hallmark of the Punk community is a group of people with fashion, makeup styles and clothes that are not commonly worn [3], [7]. Hairstyles stand with striking bright colors that people usually call Mohawk hair, then super tight jeans paired with shabby clothes. And knick-knacks accessories like chains hanging from his pants pockets, iron rings around his hands, shoes black cloth, pierching installed on the lips or ears as well as various other accessories, as a differentiator with normal clothes commonly used by the people in general [4], [11]. They often walked in groups and kept quiet in the corners of big cities [12].

Punk's behavior is considered deviant behavior [13], because it is reflected in fashion and life styles that are different from the community in general [3], but apparently they have their own creativity [13] nd not all Punk communities are alcoholics. Fashion Punk is a subculture that is identical to the ideology do it your self (DIY) [3], [5], [7], [14]. They express themselves in an extraordinary way and impressed create alienation in society [4], that is, clothing or accessories used are inappropriate objects [15], such as safety pins, clothespin clothing of plastic, component $\mathrm{TV}$, razor and tampons. $\mathrm{T}$ shirts used by punk fashion teenagers are usually covered in blood, green and red painted hair with a spike, mohawk, bihawk, or trihawk style. punk's fashion is considered to be radical, anarchic and rebellious [16]-[18].

There is a considerable difference in punk in access to public spaces, radio stations, clothing styles and musical performances [19]. Punk is not an ordinary community, they have ideology and do politics in their own way [2]. punk's political attitudes involve three components, namely cognitive, affective and evaluative [20]. Punk embrace truth values, economic values, aesthetic values [15], [21], social values, and religious values in their own way [22].

Punk is actually a type of music that is very idealistic, as well as its adherents [13]. Fans are not only among young people but also among the elderly [20]. They are not merely expressing their level of musicality in the form of songs, but rather, as a means to convey criticism of socio-political phenomena [2], [17], anarchy, violence, resistance, deviations of government power and arbitrariness of policy makers [11], [23]. Punk activity carries out social criticism of government through its musical works [24]. The songs produced by punk are different from other songs and are 
rarely heard by audiences because the songs contain social criticism and criticism of the government [2], [3].

Factors that influence punk embrace a value that is based on individual characteristics and social environment [25]. The form of the punk's truth value is free spirit to be themselves [4], [26]. Many friends and are free to show the work is a form of economic value [27].

Although most people think punk has been neglected in analytic aesthetics, punk can explain the nature, boundaries, and value of art. Punk deliberately violates the aesthetic norms that are held widely but with an appreciation of art able to find beauty or aesthetic value but also about selfbuilding [28]. The form of punk's aesthetic value is very caring for each other. Mutual help helps without expecting any reward and considers all human beings equal.

Punk is not only among non-religious, but also has religions such as Islamic punk, namely Islamic youths who do not identify themselves in any way and make a place for themselves in the punk and Muslim world [29]. Religious values are manifested in the form of raising funds for the poor as a substitute for worship [30].

One representation of nationalism in the flow of Punk Rock music is in music. Punk sense of nationalism is reflected in the concern for history [31]. The sense of nationalism that was packaged through the mass media that emerged through a series of texts contained in the video clip of the Band Group with the Punk Rock genre [31]. The use of klip video is a legend in raising the biological wealth and cultural diversity and the importance of tolerance in Indonesian society which is currently exposed to the issue of religious domination, regional conflict and discrimination against minorities. Nationalism is more a cultural phenomenon than a political phenomenon because it is rooted in ethnicity and premodern culture. Nationalism should be in every young generation in this country, including young people who choose their lives to become a punk.

Various studies of punk have been done among them in the countries of Britain, America, China, which revealed a lot of deviant behavior of the Punk community. From various studies there have been no studies of punk on the level of perspectives on nationalism attitudes in themselves, so the focus of this research study is on a marginalized minority group that has unique characteristics compared to other groups, namely punk. In addition, this research also aims to find out how their nationalism is towards this nation and state because of the scope of civics studies and also the problem of nationalism in society.

\section{METHODS}

This study uses qualitative research methodology. In using this method the researcher as participant observation. Data collection method used is field research with phenomenological research design [32]. The subject of this study is the Punk Street Rebelian Probolinggo community. The location of the study was chosen because it is one of the cities in East Java and is the largest punk base compared to other cities in East Java. The determination of informants in this study is through snowball sampling. Data collection techniques through participatory observation methods and in- depth interviews. Data analysis techniques are carried out through four stages: data collection, data reduction, display data and conclusion verfication [33].

\section{RESULTS AND DISCUSSION}

\section{A. The Identity of Indonesianness in the Punk Rebelian Community}

Punk culture in people's lives is considered as the age of teenagers who are in search of identity. Interest in entering the punk community is able to form self-identity and ideology as punk members.

1) Rebelian punk street community at Probolinggo: Based on the data in the field, there are several reasons for the probolinggo youth to become rebelian members of Punk. Starting from the reason to find a place to hang out, want to feel the difficulties of living on the road to the desire to seek identity and a sense of dissatisfaction with the government, or protest against freedom that is restricted.

"...I used to join the SID community (Indonesian punk rock band Superman Is Dead, ed) when on the way to Jember I saw a lot of Punks sitting in a circle on the street ... I was curious there ... it turned out that one pack of rice was at least eaten by five people. So I have this thought: this is my soul ..." (Toni, 19th)

Most of the respondents who got into the Punk community were the factors that followed up until they finally felt comfortable with the environment.

\section{"...If I started with punk, there was a junior who was senior. The average punk punk is still wobbling in the search for identity so they sometimes want to show themselves as the Punk community ... this is how I am ... but if I am a long time rich I am quite proud to only be known as the punk street rebelian Probolinggo" (Fajar, 32th)}

From the results of observations carried out the characteristics of the Punk rebelian community in Probolinggo are generally the same as the Punk community in general. Their style tends to be creepy that sometimes makes people afraid when they meet this community. Their free association is vulnerable to destructive lifestyles, such as Free Sex, Drugs, Liquor.

"... Punk there are two kinds of kak, punk street with punk rock. If punk street is usually on the streets if punk rock is using a motorcycle or BMX bike. The punk rock is usually central to Punk Rock DIY (Do It Your Self, -red) ... "

There are some Punks who take advantage of their "eeriness" to commit crime. But there are also communities that channel their musical creativity by forming band groups that sing songs entitled Nationalism.

"... The Punk boy just seems to feel like it, but I never bothered the most only girl. The punk boy knows the limits of religion are also afraid of God. In fact, sometimes girls who are convinced of photos ..."

For their own clothing, leather jackets and leather pants became one of their mainstays, but there were also Punkers who used jeans that were very tight and combined with t- 
shirts bearing the names of their bands or criticism of the government. For hair usually spike or mohawk style is their mainstay. For this hairstyle, there are many ordinary people who follow it because it is very interesting, but sometimes it creates an impression of responsibility. Body piercing, chains and bracelets spike become one that they must wear. For shoes, besides high boots, Punkers also use sneakers, but only Converse sneakers that they wear do not forget to bring attributes to show their Indonesian like a red and white flag or just a slayer that reads Indonesia.

Observations show Punk Street Rebelian behavior deviant social behavior. This is evidenced by the behavior of Punk who often consume alcoholic beverages and illegal drugs, even researchers are invited to go to the pharmacy to buy drugs commonly consumed by Punk.

\begin{abstract}
"... during the daytime punk usually gather behind the market to drink liquor, play music and sing together. I myself am most pleased with singing a great Indonesian song with the Superman Is Death song for Indonesia. For us creations are not traditions but prices that are not bought and for us the streets are schools. But remember don't think of us as rubbish. Garuda in my chest, Indonesia my homeland, NKRI is dead." (Angga, 20th).
\end{abstract}

Nationalism is a manifestation of state consciousness or the spirit of statehood. In essence, the form of nationalism that lives on the people and the rulers in an independent country that is with all its strength to maintain the sovereignty of his country and work for the glory of his country. The national spirit develops towards the pride of state.

2) All Indonesians are my brothers: Punks think that all people are friends and brothers without any seniority and juniority. All the same and equal / equal, punk considers the togetherness of fellow punk to each other will make them united and stronger.

"...Punk will never die boss ... we are a community of Public United Not Kingdom. There is no caste for us all equally. The same weight is carried lightly as well ... everyone in this country is our brother" (Toni, 19th)

Representation of unity and unity for all Indonesian people in accordance with the fifth principle of Pancasila is contained in the slogan of the Punk street Rebel community as Tanu, 18th said, "... we are not the same but we can both create an atmosphere of security, peace, peace, get along well in this country of Pancasila that we love..."

Although there has been a conflict between one of the personnel, they can solve it by means of deliberation, but even though they are identical with actual violence they also still apply the spirit of togetherness, solving problems with deliberation. They also explained to us that the punk community is not just to make riots everywhere or rubbish, the punk community is just to find their identity. Although they also often challenge the government.

3) Motto bineka tunggal ika is my life principle: The positive and negative influences of this community, return to the perspective of the community itself. Indeed, some Punk communities have a negative impact on someone, especially teenagers whose souls are still unstable and do not understand the meaning of Punk itself. Actually Punk's children are free but responsible. This means that they also dare to be personally responsible for what they have done. Because the flow and lifestyle of the Punkers are indeed very strange, the slanted views of the people are always aimed at them. Even though many Punkers have social concerns

"... we are different from Anjal, our family is still there and we go home. Even though we are from different regions, we are brothers. Unity in Diversity for us is not an ordinary slogan but has become a principle of life. Punk is a community while anjal is not, there are even some of them who do not return home and hang up on the streets (Fajr, 32) yearly "

From the results of the interviews the researchers really took a hat off to the PUNK rebelian community who were able to proudly show their love for the motherland and the country of Indonesia. The solidarity they maintain reflects true diversity. As stated by Isaac, 25th.

"Do you know what is unity in diversity? We love our country. Even at every event we held reforestation, routine trash on the streets. Where are people doing this now (now, red-). Our physique is dirty but our hearts are not as dirty as you think. We love our country. Our principle Punks are my mother, your mother, our mothers. Your wound is our wound ..."

The identity of the Indonesian people must be based on the values of Pancasila. The Pancasila value includes: (1) The Belief in One Almighty, (2) Fair and Adherent Humanity, (3) Indonesian Unity, (4) Popular Leadership by Wisdom in deliberating representatives, (5) Social justice for all Indonesian people. Values that are in line with the five pillars of the character of Pancasila: a) Transcendence: realizing that humans are the creation of God Almighty. From him will bring servitude solely to the Almighty God. This awareness also understands the existence of self and the surrounding environment so that it is able to prosper, b) Humanization: every human being is essentially equal in the eyes of God except the knowledge and piety that distinguishes it. Humans are created as subjects that have potential, c) Diversity: awareness of so many differences in the world, but able to take common ground to grow power d) Deliberation: Liberation (emancipation) of the oppression of fellow human beings. Punk is not an ordinary community, they have ideology and do politics in their own way.

4) My ideology song: Song lyrics are a form of one's expression about something that has been seen, heard or experienced. In expressing his experience, songwriters perform word plays in language to create attraction and distinctiveness towards the lyrics or lyrics. The lyrics of the song are formed from the language produced by the communication between the songwriter and the audience.

Punk Street Rebelian community expresses their dreams and aspirations through the songs they create. One of the following Punk Street community songs is an example of footage of dreams and forms of protest against the government. 


\begin{abstract}
"Here we will continue to stand, here we live and die as our full reconciliation runs Punk Street Indonesia is only one of our commitments Indonesia Punk will never die just one of our determination Punk Street Indonesia. Sustainable country from people's sweat, distribution and money from people's sweat. When we spend money on debauchery officials when we pay taxes to buy various weapons. When weapons are used turn around to attack us "
\end{abstract}

The footage of the song is a reflection of the positive anarchism of the Punk community towards the regional government in particular and the Indonesian government in general. The Punk Community hates injustice when a rich group gets richer and the poor are increasingly oppressed. When they are orderly paying taxes, the public money is used only to buy weapons, which is then used by PP police officers to beat, threaten, and even shoot punk because they are considered as vandals.

\section{B. Form of Punk Street RebeL Community Nationalism}

Nationalism is more a cultural phenomenon than a political phenomenon because it is rooted in ethnicity and premodern culture. Nationalism should be in every young generation in this country, including young people who choose their lives to become a punk. The implication of Puk nationalism is manifested in several activities including 1) music 2) Rejection of injustice 3) love for the environment 3) volunteering for humanity and 4) taking action to defend the country.

1) Refusing injustice: Freedom for punk is the freedom to regulate and control from themselves. So everything comes from self-awareness to act and do something. Usually if they already think like that punk will work on the initiative of themselves and do not need to be regulated and regulated by others. Such a mindset will lead to an independent attitude, which in the punk community they usually use philosophy and the slogan of DIY (Do It Yourself) or commonly interpreted as "be yourself".

"... Indonesia is a rich country but there are no rich people. If there are riches, there is nothing but solidarity, the mutual help of each other is not in Indonesia. Outsiders who come are considered kings, while the natives are their helpers. This is us Punk where we balk at the absence. We are fed up with the law in Indonesia which is always pointed down but blunts up ... "“

Development is often associated with nationalism and lately the relationship has been emphasized by referring to emerging countries in Africa, Asia and Latin America. in these countries, including Indonesia, there can be witnessed a new nationalism based on shared cultural traditions such as a single language or dialects related to the gathering of customs, and common interests of the community, symbols of national experience including flags, national anthem , parades, processions, pilgrimages, institutional solidarity, including a single government, state sovereignty, territorial units and principles of loyalty and a feeling along with national awareness in the minds of the people.

2) Love the environment and humanitarian volunteers: The Punkers usually have a very attractive way of dressing, not even a few people who are not Punkers imitate their makeup. Sometimes the style of the Punkers is also combined with the current style of dress which ultimately actually damages the image of the Punkers themselves.

"... should by choosing to live as a Punk we can be ourselves by standing on our own feet in challenging the rigors of the world. Why must be someone else or another nation. When you have become a punk, aren't people from other nations proud of their own culture and country. We should be able to learn more and understand what Punk is ... "

Punk is a minority group that is marginalized and has unique characteristics compared to other groups. But what is behind their nationalism attitude towards this nation and state because in the scope of the civics study the problem of nationalism in society is urgent in the era of increasing discrimination in this country.

3) Action to defend the country: The life of the punk community, especially in the Probolinggo community, was not as bad as imagined. Among those who are often identified with drug alcohol free sex brawls and violations of all existing norms still keep a love of God and their country. Some of them admit to being God and acknowledging their religion even though sometimes they don't do the duty of a Muslim.

"For country action, we have volunteered for victims of natural disasters. most Punk kids are valued negatively with society. They just see us from the outside. Our appearance is different, but what is the treatment and perception of the community towards us must also be different. There is no prohibition or law that prohibits people or communities from appearing differently. God willing, if so we have a special event which is to hold a punk rock music event called Indonesia united. The event is on August 1, 2018 with a ticket price of 15K. Most of the benefits we get will be donated to diabetics of our brothers in Jakarta, namely the Muslim Punk community.."

Some of the punk rebelian community of Probolinggo even admitted that they had joined the 212 solidarity action at the Jakarta National Monument. They did not want the State of Indonesia to be led by a religious observer. This was reflected in Adam's recognition of his experience participating in the Punk Muslim demonstration in Jakarta.

\begin{abstract}
"Only a few people we believe in this country, We believe there is no God but Allah, we believe in the words of our father's mother, we appreciate our heroes Ibu Kartini and Marsinah. Their sacrifice to this country arrived at the level of sacrificing lives. If Indonesia is led by a ruler who does not want to respect religious differences and even make fun of other religions, we are ready to install the body for the future of this country ... " (Adam)
\end{abstract}

It is difficult indeed to separate punk with a negative stigma attached. Punk is synonymous with lower-class life that is vulnerable to dealing with crime. Giving negative values to people involved in punk may be different when knowing the perception of nationalism from this community. As stated by Fajar, 32 years. 


\begin{abstract}
"... by being Punk means we have to be a nationalist, because Punk gives us the freedom to be ourselves. Loving bloodshed where we were born and raised. Stand up independently for the progress of the country we love, no matter how ..."
\end{abstract}

From this statement we cannot avoid again that marginal communities in the eyes of this society behave nationalistly. Deviant community behavior is a form of strong protest against acts of violence and corruption rampant in this country. The hopes and aspirations of independence for this country have also become the dreams of punk, because they are part of Indonesia.

\section{CONCLUSIONS}

Based on the results of the study, it can be concluded that there was a disorientation towards the problem of nationalism for the Punk people. The identity of the Punk community in Indonesia can be seen from the spirit of brotherhood, the principle of Bhinek Tunggal Ika life, and the spirit of loving the nation. The implementation of nationalism is implied in the daily life of the Punk Street Rebelian community, which is through urakan appearance as a form of protest against inequality, love for the environment, and some solidarity actions to defend the country. Punk doesn't think of other people's lives. The principle is hedonism (pleasure measured from oneself) but they remain in love with their country.

\section{ACKNOWLEDGEMENT}

Thanks to the Probolinggo Punk Street Rebelian community who have become informants in this article.

\section{REFERENCES}

[1] K. James, “'This is England': Punk rock's realist/idealist dialectic and its implications for critical accounting education," Account. Forum, 2009.

[2] D. Clark, "The raw and the rotten: Punk cuisine," Ethnology, 2004.

[3] I. P. Moran, "Punk: The Do-It-Yourself Subculture," Soc. Sci. J., 2010 .

[4] K. C. Dunn, "Never mind the bollocks: The punk rock politics of global communication," Rev. Int. Stud., 2008.

[5] N. Griffin, "Gendered Performance and Performing Gender in the DIY Punk and Hardcore Music Scene,” J. Int. Womens. Stud., 2012.

[6] R. MOORE, "Postmodernism and Punk Subculture: Cultures of Authenticity and Deconstruction," Commun. Rev., 2004.

[7] R. Moore, "Friends don't let friends listen to corporate rock: Punk as a field of cultural production," J. Contemp. Ethnogr., 2007.

[8] J. R. Davis, "Growing Up Punk: Negotiating Aging Identity in a Local Music Scene,” Symb. Interact., 2006.
[9] R. Doane, "The habitus of dancing: Notes on the swing dance revival in New York City," Journal of Contemporary Ethnography. 2006.

[10] S. Widdicombe and R. Wooffitt, “"Being' versus 'Doing' punk: On achieving authenticity as a member,” J. Lang. Soc. Psychol., 1990.

[11] L. Langman, "Punk, porn and resistance: Carnivalization and the body in popular culture," Current Sociology. 2008.

[12] C. Lahusen, "The aesthetic of radicalism: The relationship between punk and the patriotic nationalist movement of the basque country," Pop. Music, 1993.

[13] J. Förster, R. S. Friedman, E. B. Butterbach, and K. Sassenberg, "Automatic effects of deviancy cues on creative cognition," Eur. J. Soc. Psychol., 2005.

[14] K. R. Culton and B. Holtzman, "The growth and disruption of a "free space': Examining a suburban Do It Yourself (DIY) punk scene," Space and Culture. 2010.

[15] M. Sklar and M. DeLong, "Punk Dress in the Workplace: Aesthetic Expression and Accommodation," Cloth. Text. Res. J., 2012.

[16] L. Pendry and R. Carrick, "Doing what the mob do: Priming effects on conformity," Eur. J. Soc. Psychol., 2001.

[17] J. Brown, P. Deer, and T. Nyong'o, "Punk and Its Afterlives: Introduction," Soc. Text, 2013.

[18] J. Stratton, "Jews, punk and the holocaust: From the Velvet Underground to the Ramones - The Jewish-American story," Popular Music. 2005.

[19] A. O'connor, "Punk and globalization: Spain and Mexico," Int. J. Cult. Stud., 2004.

[20] A. Bennett, "Punk's not dead: The continuing significance of punk rock for an older generation of fans," Sociology. 2006.

[21] S. Thompson, Punk productions : unfinished business. 2004.

[22] A. McDowell, "Warriors and Terrorists: Antagonism as Strategy in Christian Hardcore and Muslim 'Taqwacore' Punk Rock," Qual. Sociol., 2014.

[23] D. Simonelli, "Anarchy, Pop and Violence: Punk Rock Subculture and the Rhetoric of Class, 1976-78," Contemp. Br. Hist., 2002.

[24] T. Triggs, "Scissors and glue:: Punk Fanzines and the creation of a DIY aesthetic," J. Des. Hist., 2006.

[25] W. Ryan Force, "Consumption Styles and the Fluid Complexity of Punk Authenticity," Symb. Interact., 2009.

[26] D. Beer, Punk Sociology. 2014.

[27] P. Guerra, “Just can't go to sleep': DIY cultures and alternative economies from the perspective of social theory," Port. J. Soc. Sci., 2017.

[28] J. Prinz, “The aesthetics of punk rock," Philosophy Compass. 2014.

[29] A. T. Fiscella, "From Muslim punks to taqwacore: An incomplete history of punk Islam," Contemp. Islam, 2012.

[30] P. Guerra, "Raw Power: Punk, DIY and Underground Cultures as Spaces of Resistance in Contemporary Portugal," Cult. Sociol., 2018.

[31] B. J. M. Turrini and R. High, "“" Well I Don”' T Care About History ": Oral History and the Making of Collective Memory in Punk Rock," Notes, 2013.

[32] J. W. Creswell, "Research design: Qualitative, quantitative, and mixed methods approaches," Res. Des. Qual. Quant. Mix. methods approaches, vol. 3rd, p. 260, 2009.

[33] M. A. Miles, "Miles and Huberman (1994)- Chapter 4.pdf," in Qualitative Data Analysis: An Expanded Sourcebook, 1994, pp. 5072 . 